\title{
Funtzio anitzeko polimero metal-organiko porotsuak (MOF): etorkizuneko material adimendunei begira
}

\author{
(Multifunctional porous metal-organic frameworks \\ (MOFs): quest for future smart materials)
}

Javier Cepeda

Polimeroen Zientzia eta Teknologia Saila. Kimika Fakultatea. Euskal Herriko Unibertsitatea (UPV/EHU).

Kimika Aplikatua Saila. Kimika Fakultatea. Euskal Herriko Unibertsitatea (UPV/EHU).

javier.cepeda@ehu.eus

Sonia Pérez-Yáñez

Kimika Ez-organikoa Saila. Zientzia eta Teknologia Fakultatea. Euskal Herriko Unibertsitatea (UPV/EHU).

sonia.perez@ehu.eus

DOI: $10.1387 /$ ekaia.16220

Laburpena: MOF deritzen polimero metal-organikoak ioi metalikoz eta estekatzaile organikoz osatutako koordinazio-sare porotsuak dira. Azken urteotan beste material porotsuen artean gailentzen ari dira. Bere natura hibridoak propietate anitzak jorratzeko aukera ematen die, porositatearekin erlazionatuta daudenez gain (gasen bilketa eta banaketa) katalisia, sentsore magnetiko edota lumineszente bezala jokatzekoak ere bermatuz. Material hauek egitura eta funtzionalitatea aldatzeko erraztasun handia dutenez, aldi berean ikatz aktibatuaren eta zeoliten barne-azaleren mugak gainditzen dituzte. Hori dela eta, MOFen arloak garapen sakona sustatu du eta kimikaren barnean hazkunde azkarrenetariko esparrua izatea lortu du.

Hitz gakoak: polimero metal-organikoak, gasen adsortzioa, gas-banaketa, katalisia, sentsore lumineszenteak.

Abstract: Metal-organic frameworks (MOFs) are an emerging class of porous coordination networks constructed from metal ions and organic linkers. This hybrid nature benefits them from applications not only related with porosity (storage and separations of 
gases) but also catalysis, magnetic and/or luminescent sensors among others. The structural and functional tunability of these materials, with record-setting surface areas surpassing activated carbons and zeolites, has prompted a yet unknown development and become the area of MOFs one of the fastest growing fields in chemistry.

Keywords: metal-organic frameworks, gas storage, gas separation, catalysis, luminescence sensors.

\section{SARRERA}

MOF (ingelesez Metal-Organic Frameworks) deritzen polimero metalorganikoek, azken bi hamarkadetan, material porotsuen munduan iraultza sorrarazi dute. Porositate itzelak (bolumen hutsak: \% 90 arte) eta ikaragarrizko barne-azalerak $\left(7.000 \mathrm{~m}^{2} / \mathrm{g}\right.$ arte) dauzkaten konposatu kristalinoak dira. Hain zuzen ere, MOFak estekatzaileen eta nodoen arteko loturen (koordinazio-loturen) ondorioz eratzen diren egitura molekularrak dira. Estekatzaileak atomo emaileak dituzten molekula organikoak dira, eta nodoak metal edo kluster metalikoak. Egitura barruan gordetako poroak molekula ostalariak harrapatzeko, eta kasu batzuetan, erreakzio kimikoetan parte hartzeko oso egokiak dira. Gainera, material hauek beste material porotsuekin (zeolitak, karboi aktiboak) konparatuta abantaila nagusia daukate: beraien egitura zehaztasun osoz diseinatzeko erraztasuna (1. irudia). Izan ere, gaur egun 20.000 ale baino gehiago ezagutzen dira. Bereziki, egitura hauek topologia anitzetan sailka daitezke, eta asko naturan sorturiko mineraletan oinarrituta daude. Era horretan, propietate eta funtzio zehatzak dituzten egiturak diseinatzea ahalbidetzen dute konposatu hauek, eta materialak ikertzen dituzten zientzialarien ametsari edo xedeari eusten diete. Funtsezko mailan, MOF konposatuek egitura kimikoen edertasuna eta kimika organikoa eta ez-organikoa bateratzeko ahalmena erakusten dute, tradizionalki bereizirik ikusi diren bi jakintzagaiak lotuz. Hori dela eta, 1990eko hamarkadatik aurrera kimikako arlo honek hazkunde handia jasan du, ikerkuntza-artikuluen kopuru handiak eta etengabe garatzen ari diren aplikazioen irismenak agerian jartzen duten bezala. Konposatu hauek osatzen dituzten atal organiko eta ez-organikoek erakusten duten aldakortasun graduari esker aplikazio potentzial desberdinetarako interesa piztu dute, gehien bat energia berriztagarrien sailean (hidrogeno eta metano gasen biltegi molekular gisa) eta gasen purifikazioarekin erlazionatuta (gasen bereizketak ahalbidetu ditzaketen ahalmen handiko adsorbatzaileak garatzeko). Hala ere, beste aplikazio batzuetarako ere garrantzitsu bihurtzen hasi dira, esate baterako, mintzak eratzeko, katalisian edota irudi biomedikoak garatzeko oso erabilgarriak izan daitezkeelako.

Hasiera batean, MOFak ahulegiak zirelako sinesmena hedatu zen zientzia mailan, maiz, aurretik harrapatutako molekulak askatzean egitura orokorra suntsitzen baitzen. Horregatik, zientzialari batzuen ustez, produktu hauek inoiz ez zuketen erakutsiko zeolitek industria mailan iragazteko eta 


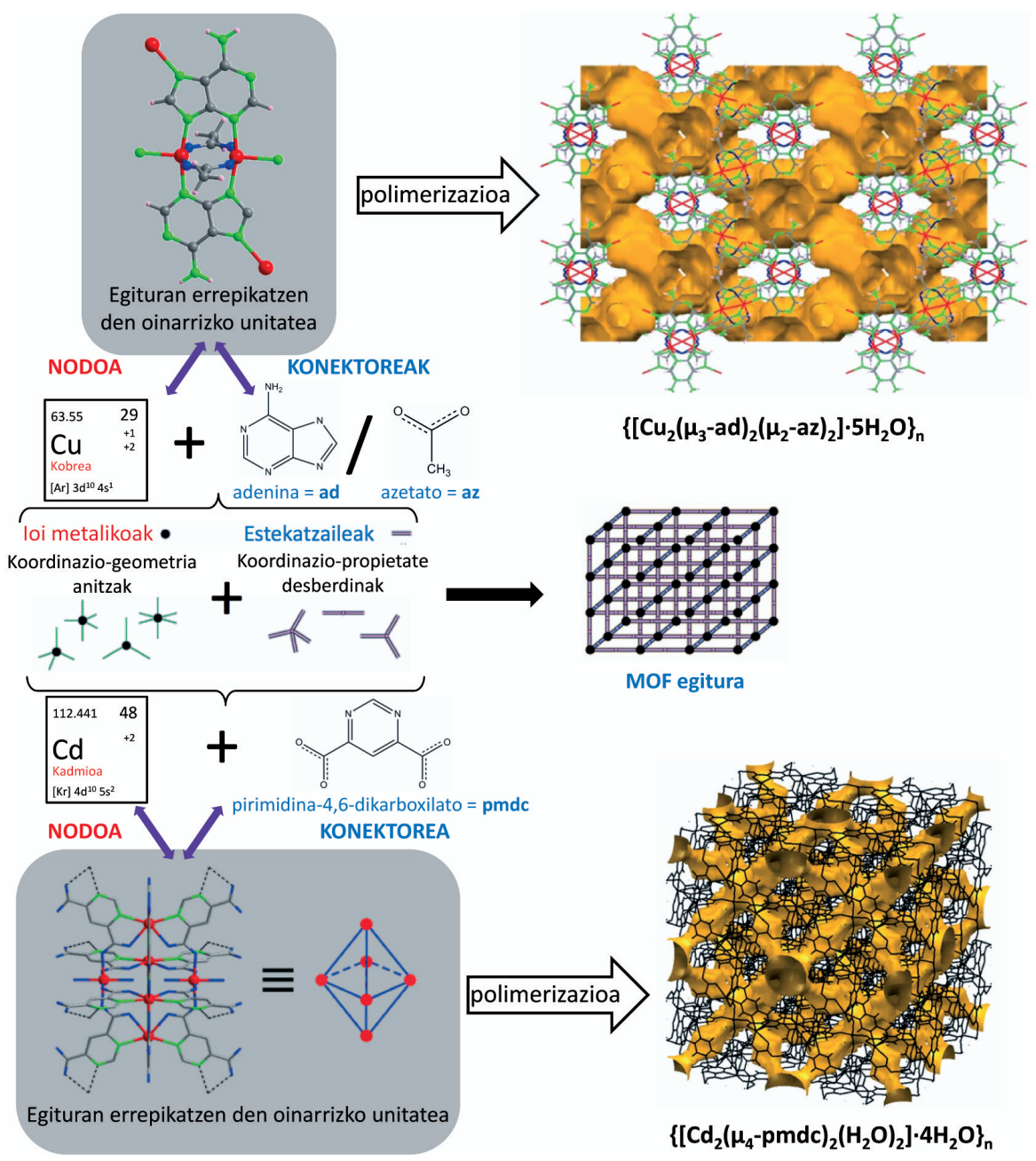

1. irudia. MOF konposatuen egitura kristalinoaren hazkundea bere funtsezko unitateen loturetatik.

katalizatzeko erakusten duten ahalmena. Hala ere, urte batzuk geroago, eta milaka laborategietan gauzatu den esfortzuagatik, MOF materialak aplikazio komertzialetan debuta egiteko prest daude, eta zientzialari horien ustea suntsituko dute. 


\section{PORO HANDIAGO BATEN BILA: MOF POROTSUEN TXAPELKETA}

MOFen ikerkuntzan gertatutako garapena 1999an du jatorria, ezohiko sendotasuna aurkezten zuten bi konposatu agertu zirenean: Hong Kong -eko Zientzia eta Teknologia Unibertsitateak garatutako HKUST-1[1] eta Michigan Unibertsitatean sintetizatutako MOF-5 [2]. Bigarrenak gramoko 2.300 metro karratuko barne-azalera dauka, hau da, zortzi tenis-zelai baino gehiago estaltzeko azalera. Datu horrek, hain zuzen, aurrerapauso galanta ekarri zuen, momentu hartako konposatu porotsuek erakusten zituzten barne-azalerako mugak hautsi zituelako. Parametro hori handitzeak konposaturen gainazalean molekula ostalariak finkatzeko toki gehiago eratzea dakar, adsorbatzaile eraginkorrak garatzeko ezinbesteko erronka dena. Aitzitik, MOF konposatuek aurkezten duten eragozpen handienetariko bat tenperaturaren edo disolbatzaileen aurreko egonkortasun txikia da; aldiz, zeolitak bezalako solido ezorganikoek oso tenperatura altuak jasaten dituzte. Alderdi horretatik, MOF egonkorrak eta sendoagoak eratzeko gakoa ioi metalikoen ordez metalez osatutako klusterrak (katioi metaliko eta atomo ez-metaliko gutxi batzuen elkarte sendoa) erabiltzean datza. Horretaz gain, klusterren geometriak eta antolamendu espazialak kristalaren arkitektura orokorra bideratzen du, eta, haiei estekatzaile organikoak lotzen zaizkienean, arkitektura edo topologia berriak diseinatzeko kontrola ezartzea ahalbidetzen dute. Bi osagarri horien (kluster eta estekatzaile organiko) kopurua etengabe handitzen ari da, eta horrek egitura berriak moldatzeko gaitasun handiagoa eskaintzen die MOFei zeolitekin konparatuz. Era horretan, aplikazio zehatz baterako aproposenak diren poro eta propietate kimikoak dituen egitura berriak diseinatzeko aukera paregabea eskaintzen dute. Gaur egun $500{ }^{\circ} \mathrm{C}$-ko tenperatura edota astebetez metanolean irautea jasan dezaketen MOFak ezagutzen dira; beste batzuek MOF-5-ak daukan barne-azalera hiru aldiz gainditzen dute, barruan proteina gizenak egokitu ditzaketenak [3].

\subsection{Gasen bilketa}

Etorkizunari begira, MOFen erronka garrantzitsuenetariko bat gas erregai edota kutsakorren bilketa prozesu eraginkorragoak garatzean datza. Konkretuki, sortu berri den MOFen merkatuak metanoaren $\left(\mathrm{CH}_{4}\right)$ bilketaren gainean jarri du arreta. Metanoa merkea eta eskuragarria izateaz gain, gas hau erabiltzen duten kotxeek kostuak eta karbono dioxidoaren $\left(\mathrm{CO}_{2}\right)$ isuriak murrizten dituzte [4]. Hala ere, gaur egun metano gasa biltzeko era bakarra sekulako eta garestiak diren ontziak erabiltzera mugatuta dago, eta horrek erregai honen erabilera eragozten du. MOF materialak arazo horren irtenbidea bilaka daitezke, $\mathrm{CH}_{4}$ molekulak ondo harrapatzeko tamaina eta propietate kimiko zehatzeko poroak dituzten konposatuak sortuz gero. Horretarako, ikertzaileek erabiltzen duten estrategiarik garrantzitsuenetariko 
Funtzio anitzeko polimero metal-organiko porotsuak (MOF): etorkizuneko material adimendunei begira

bat poroaren gainazalean eskuragarriak diren ioi metalikoak kokatzea da. Behin materialean gasa igarotzen hasten denean, ioi horiek metano-molekularen elektroi-hodeia distortsionatzen eta polarizatzen dute, eta ondorioz, haienganako elkarrekintza erakargarriak eragiten dituzte. Orain arte ikertutako MOF onenek metanoa biltzeko ontzi huts baten kapazitate bikoitza dute, eta, era berean, gasa erraz askatzen dute eta presioa jaitsi egiten da. Beraz, adituen esanetan, automobiletarako metanoaren bilketa gainditutako arazoa dela esan daiteke.

Bestalde, MOFek garraiobideen munduan erabilera garrantzitsuagoak ere izan ditzakete erregai-piletan oinarritzen diren ibilgailuak garatzeko beharrezkoa den hidrogenoaren bilketa hobetuz gero [5]. Tenperatura baxuetan hoztutako gasa presio altuetan konprimitzea konplexua eta garestia da. Aldiz, baldintza horietan jardungo zuketen biltegien ordez MOFak erabiltzeak, momentuz, desafio zaila izaten jarraitzen du. Adibide moduan, orain arte ikertutako material guztien artean nikelez osatutako MOF batek marka hautsi egin du, hidrogenoari gogor lotzeko ahalmena erakutsi baitu [6]. Esate baterako, 12,5 gramo gas litroko biltzeko gaitasuna du giro-tenperaturan eta 100 bar-eko presiopean. Emaitza hauek, zoritxarrez, AEBetako Energia Sailak (DOE) 2020 urterako ezarri duen jomugatik (baldintza horietan 40 gramo litroko) oso urrun daude. Ondorioz, aurreko helburua erdiesteko, ikerlariok propietate hobeak dituzten MOF berriak ikertzeko ardura daukagu.

Atal honekin amaitzeko, ingurumenarekin erlazionatutako arduren artean, MOFen ikerketen ardatz batek karbono dioxidoaren isurpenen handiagotzearekin bat egiten du. Izan ere, isurpen horiek energia ekoizteko erregai fosiletan dute eratorria (mundu mailan \% 80), eta etorkizunean handitzeko joera daukate hazkunde ekonomiko eta industria-garapenagatik [7]. Karbonoan oinarritutako azpiegiturak pixkanaka energia garbiekin ordezkatu arren, aldaketa sakona gauzatzeko behar den teknologia ez dago oraingoz garatuegia industria mailan txertatzeko. Hortaz, karbonoaren harrapaketaren eta bahiketaren teknologiak, errekuntza prozesuetan bertan aplika daitezkeenak batez ere, ezinbesteko papera jokatuko dute eredu energetikoaren aldaketa gauzatzen den arte. Alderdi horretan, barne-azalera altuak eta gasarekin elkarrekintza eragiteko ahalmena duten MOFek jadanik bere baliagarritasuna frogatu dute. Kasurako, MOF-177 deritzon materialak ontzi huts batek baino 9 aldiz handiagoa den adsortzio bolumetrikoa du, eta, aldi berean, ohizko zeolitena baino altuagoa da [8].

\subsection{Bereizketa-saioa: bahe molekularrak}

Zientzialari komunitateak MOFek airetik zuzenean molekula zehatzak harrapatzeko ahalmena dutelako susmoa daukate, hau da, gas bat nahasketa batetik bereizteko prozesuan benetako abantaila daukatela. Hortaz, pe- 
trolioaren deribatuak lortzeko «cracking» delako prozesuan, non beroaren bidez petrolio gordinaren kate luzeak apurtzen diren hidrokarburo txikiak eratzeko, parte hartzeko interes handia piztu dute. Gas horiek bereiztea oso zaila izan daiteke, kasu batzuetan bi molekulen arteko diferentzia lotura ki-

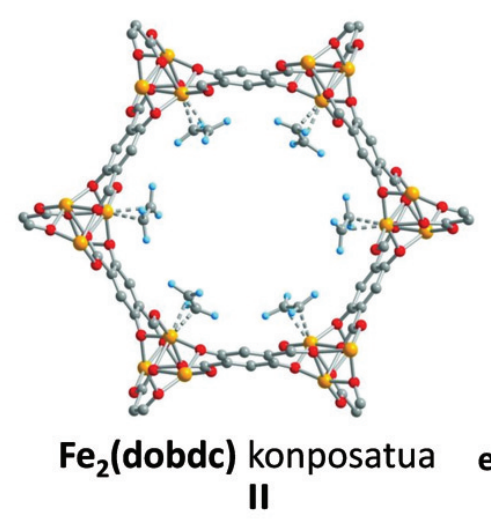

Fe-MOF-74
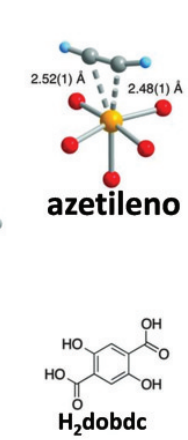

estekatzailea
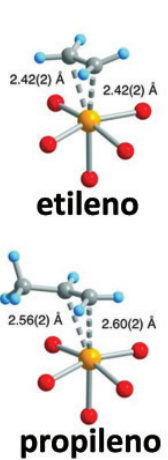

propileno
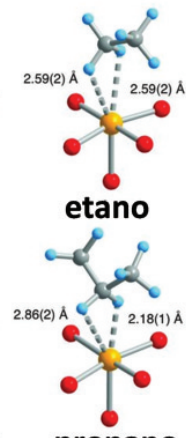

propano

\section{(a)}
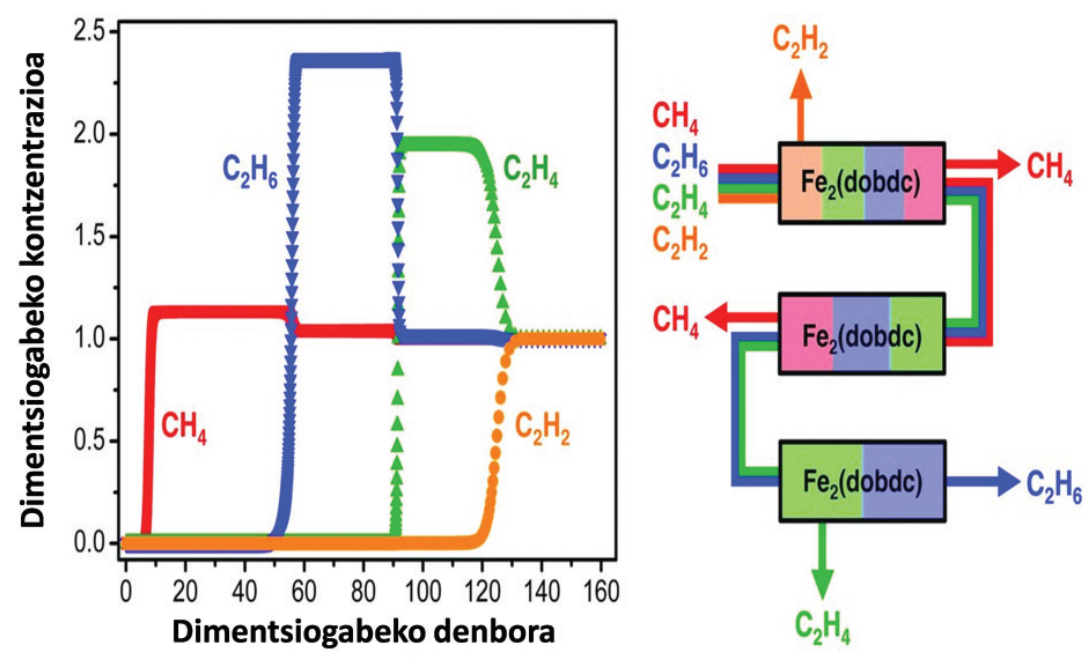

(b)

2. irudia. (a) Fe-MOF-74-aren egitura kristalinoa eta gas-molekula desberdinekiko elkarrekintzak. (b) Elkarrekintza indarraren araberako gas-molekulen arteko bereizketa. 
Funtzio anitzeko polimero metal-organiko porotsuak (MOF): etorkizuneko material adimendunei begira

miko bakar bati dagokio, propanoaren eta propenoaren artean bezala, beraien irakite-puntua soilik $5{ }^{\circ} \mathrm{C}$-tan desberdintzen baita. Une honetan petrolio-findegietan nahasketa gordina bereizteko jarraitzen den prozedura berotze-hozte prozesuan datza. Prozesu horrek ezartzen dituen tenperaturaaldaketen eraginez, eta industria mailan energia gehien gastatzen dituenetariko bat da.

Zehazki, burdin ioiez eta 2,5-dioxido-1,4-bentzenodikarboxilato estekatzailean oinarrituta dagoen Fe-MOF-74 deritzon konposatuak lana erraztu eta kontsumoa murriztu dezakeela frogatu du. Egitura kristalinoan eskuragarri dauden katioi metalikoek gertu barreiatzen diren propeno molekulen elektroiak harrapatzen dituzte eta bere mugimenduak geldiarazten dituzte. Era horretan, $45^{\circ} \mathrm{C}$-tan MOFak propanoa kanporatzen du, eta behin $\mathrm{MOFa}$ epelduz \% 99ko purutasuneko propeno korrontea askatzen du (2. irudia) [9]. Era berean, burdin ioiez osatutako beste konposatu batek, $\left.\left[\mathrm{Fe}_{2} \text { (bentzenodipirazolato }\right)_{3}\right]$ formula duena, hexanoaren isomero desberdinak (konformazio lineala edo adarkatuta) bereizteko gai da [10]. Molekula horiek materialaren poroak zeharkatzean isomero linealak triangelu itxurako izkinetan itsatsita gelditzen dira, toki horietan elkarrekintzak oso sendoak direlako. Zeolitetan, adibidez, ezin dira era horretako tokiak eratu poroen gainazalean.

\subsection{Katalizatzaileak}

Katalisia MOFen historiaren hasieratik, guztien artean gehien goraipatu den propietatea izan da. Materialen poro aldakorrek erreaktiboak kokatu, loturak apurtu eta berriak eratu ditzakete, entzima baten gune aktibo baten moduan. Orain dela gutxi arte katalizatzaile hauen gaineko garapena oso eskasa zen, berez oso MOF gutxik erakusten baitzuten egonkortasun nahiko katalisi-txanda anitz gainditzeko [11]. Egia esanda, ez dago oraingoz erreakzio kimikorik zeinentzat MOF konposatu batek emaitza hobea emango lukeen.

Hala ere, zientzialariak aurrerapenak egiten ari dira katalizatzaileen inguruan hautatutako MOF egonkor batzuetan poroen paretetan dauden talde funtzionalez baliatuz. Pauso bat harago ere joan dira, MOFaren estekatzaile edota kluster metal-organikoak eraldatzea lortu dute (loturak hautsi eta bereratzea dakarren prozesua), materialaren propietate fisiko eta kimikoak hobetuz, konposatuaren egitura kimikoa bertan behera bota gabe [12]. Prozesu horren bitartez lana asko erraztu da kimiko-sintetikoentzat, egonkortasun handiko eta, aldi berean, aktibitate kimiko nabarmeneko MOFak lortu baitituzte. Alderdi horren barruan beste erronka batzuei aurre egin behar diete material hauek, esaterako, zeolitekin erlazionatutako teknologia aurreratuagoa baitago. Egoera horrek MOF berri merkeagoak egitera behartzen du, horretarako ugariak diren metalak eta estekatzaile organiko 
merkeak erabiliz, prozesu seguruen eta ekonomikoen bidez garatuz. BASF lantegian, adibidez, tona mailako kantitateak ekoizten dituzte ura erabiliz, disolbatzaile organikoak erabili beharrean. Zeoliten poroen tamaina txikia dela eta, material horiek kataliza ditzaketen erreakzioen kopurua gutxitu egiten da, molekula handiekin zerikusia duten erreakzioak katalizatzeko desegokiak izan baitaitezke. Horregatik, MOFen poroen tamaina diseinatzeko aukerak, erreakzio zehatzetan aritzeko aproposak egiten ditu.

Aipatutako izaerari esker, MOFek izaera desberdineko erreakzioak kataliza ditzakete. Alor horretan, Knoevenagel kondentsazio-erreakzioak luze aztertu dira, zeinetan MOFek katalizatzaile moduan jokatzen duten. Horretarako, amino taldeak dituzten MOFak egokiak dira. Adibidez, $\mathrm{NH}_{2}-\mathrm{MIL}-$ 53(Al) MOFa bentzaldehidoaren eta etilzianoazetatoaren edo etilazetoazetatoaren artean gertatzen den Knoevenagel erreakzioa katalizatzeko gai da (3. irudia) [13]. IRMOF-3 izaera honetako erreakzioak katalizatzeko ere egokia da. MOF hau, aktibitate eta selektibitate altuak erakusteaz gain, oso egonkorra da eta berrerabil daiteke. Beste alde batetik, jakina da MOFak sintetizatu ostean eralda daitezkeela. Beraz, material hauen egiturari buruz hausnartuz gero, eraldaketak egin daitezke aukeratutako erreakzioa katalizatzeko asmoz.

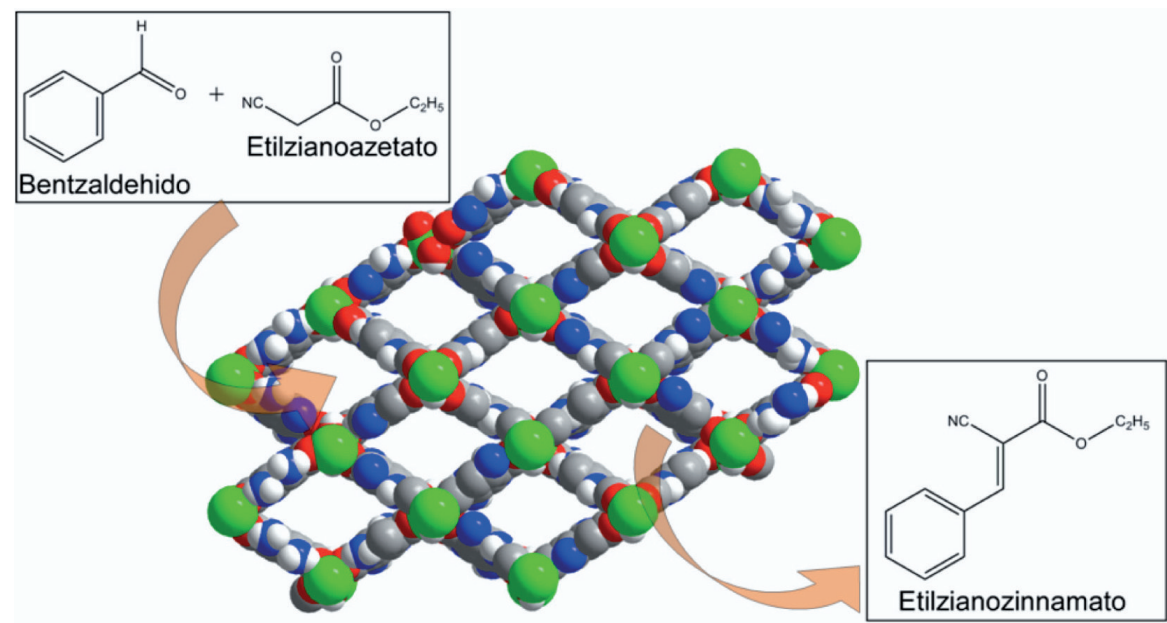

3. irudia. $\mathrm{NH}_{2}-\mathrm{MIL}-53(\mathrm{Al}) \mathrm{MOFa}$ bentzaldehidoaren eta etilzianoazetatoaren arteko Knoevenagel erreakzioaren katalizatze gisa.

\subsection{MOF lumineszenteak: etorkizuneko sentsore kimikoak}

Lumineszentzia deritzo energia xurgatzearen ondorioz argia igortzeko propietateari. Beste era batera esanda, energia handiko argia (gizakien begiarentzat ikusezina) xurgatzeko eta energia txikiagoko argia (espektro 
ikusgaian edo infragorrian kokatuta) igortzeko ahalmena daukate. Orokorrean, estimulua eragiten duen energia hori fotoien bidez egiten denez, fotolumineszentziari buruz hitz egiten da. MOFen natura hibridoa dela eta (ioi metalikoz eta molekula organikoz osatutako egitura porotsuak), era desberdinetako eta beste materialetan ezohikoak diren igorpen-fenomenoak aurkezten dituzte [14]. Alde batetik, estekatzaile gehienek sistema aromatiko eta $\pi$-konjokatuz eratutako molekula organikoak dira eta, egitura kristalinoan metalei finkatuta daudenez, argi ultramorearen bidez kitzikatzen direnean igorpen optiko edo fotolumineszentzia sorrarazten dute. Gainera, ioi metalikoek ere, ioi lantanidoen kasu konkretuan bezala, fotolumineszentzia sorraraz dezakete MOFean. Esate baterako, gertuko molekula organikoak xurgatutako energia jaso dezakete eta kolore zehatz eta distira handiko igorpenak eragin. Fenomeno orokor horietaz aparte, igorpen lumineszenteak MOFen poroetan adsorbatutako molekulek (molekula lumineszenteen kasuan) edota hauen eta poroen paretak osatzen dituzten estekatzaileen arteko elkarrekintzetan oinarritu daitezke. Izan ere, azken motako lumineszentzia erakusten duten konposatu horiek hainbat aplikazio izan ditzakete, berezko porositatea eta argi-igorpena batuz funtzio anitzeko mate-

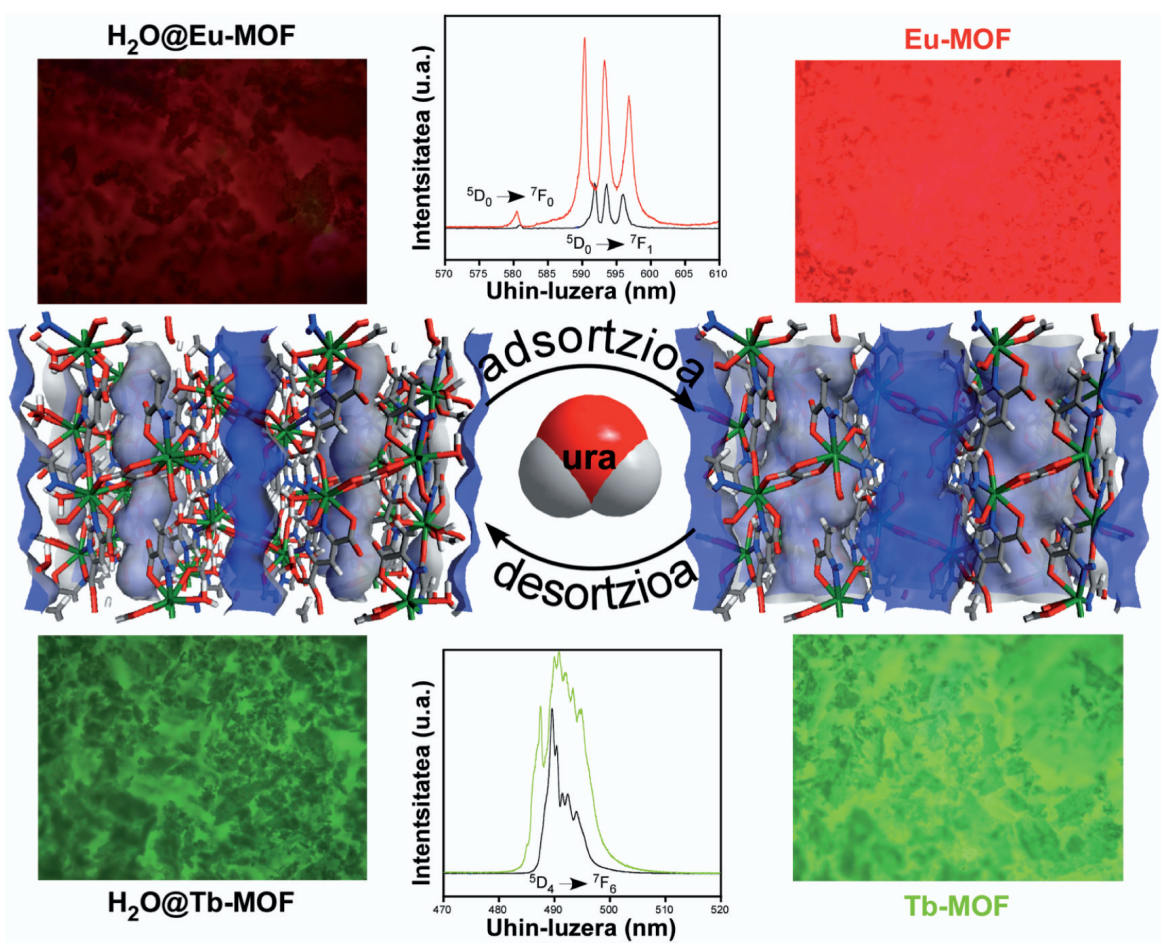

4. irudia. Uraren adsortzio/desortzioak eragindako igorpen lumineszentearen aldaketa. 
rialak lor daitezkeelako. Molekula ostalariak material porotsuaren barnean harrapatzen direnean, azken horiek propietate fotolumineszenteak alda ditzakete (adibidez, igorpen profileko maximoen intentsitate-aldaketa edo uhin-luzeran zeharkako desplazamenduak), eta ondorioz sentsoreak ekoitzi. Begi bistan sumatu daitekeen kolore-aldaketa da dudarik gabe seinale erabilgarriena sentsore gisa erabiltzeko, horrek ekipamendu espezifikorik gabeko baldintzetan lan egitea ahalbidetzen duelako. Alderdi horretan, aipagarria da lantanido ioiekin dopatutako MOF bat,[15] zeinek igorpen lumineszentearen distiran aldaketa nabarmena jasaten duen ura xurgatu eta askatzen duen heinean (4. irudia). Bestalde, era horretako korrelazioek osasunaren arloko irudietan oinarritutako teknika biologikoetan eta lehergailuen sentsoreen alorretan ekarpen garrantzitsuak ekar ditzakete. Adibide gisa, europioz osatutako MOF batek, azido dipikolinikoak (DPA, bakterien barnean ageri den molekula) selektiboki antzemateko gaitasuna erakutsi du dagoeneko. Konkretuki, konposatu horren igorpena DPArekin kontaktuan jarriz gero bost aldiz biderkatzen da [16]. LMOF-11 deritzon konposatuaren kasuan, aldiz, dinitrotoluenozko (DNT) baporeen aurrean (TNT lehergailuaren ekoizpenean derrigorrezko azpiproduktua) sentikortasun handia dauka, DNT adsorbatzean bere lumineszentziaren \% 80 itzaltzen baita [17].

\section{ONDORIOAK}

MOF konposatuak material porotsuen arloan posizio garrantzitsua duten konposatuak dira. Ioi metalikoz eta molekula organikoz eratutako egitura kristalinoetan eratutako materialak direnez, material organiko eta ezorganikoen propietaterik nabarmenenak material bakarrean batzea lortzen dute, eta funtzio anitzeko konposatuak osatzea ahalbidetzen dute. Halaber, bi osagarrien arteko konbinazioak mugagabeak direnez, aplikazio zehatz baterako bideratuta dagoen egitura kristalinoa aurrediseinatzeko aukera ematen dute, estekatzaile organiko berriak ekoiztea kimikariaren esku dagoelako eta sintesi bide anitzak daudelako. Hori guztiori dela eta, gaur egun ondo ezagutzen diren aplikazioez gain, aplikazio berriak diseinatzeko aukera zabaldu dezakete. Beraz, MOF konposatuen gaineko ikerkuntzak etorkizuneko material adimendunekiko begirada islatzen $\mathrm{du}$.

\section{ESKER ONAK}

Egileek UPV/EHUk finantzatutako doktoratu ondoko laguntzak eskertzen dituzte. 
Funtzio anitzeko polimero metal-organiko porotsuak (MOF): etorkizuneko material adimendunei begira

\section{BIBLIOGRAFIA}

[1] LI , H.; O'KEEFFE, M. eta YAGHI, O.M. 1999. «Design and synthesis of an exceptionally stable and highly porous metal-organic framework». $\mathrm{Na}$ ture, 402, 276-279.

[2] CHUI , S.S.-Y.; LO, S.M.-F.;CHARMANT, J.P.H.; ORPEN, A.G. eta WILLIAMS, I.D. 1999. «A Chemically Functionalizable Nanoporous Material $\left[\mathrm{Cu}_{3}(\mathrm{TMA})_{2}\left(\mathrm{H}_{2} \mathrm{O}\right)_{3}\right]_{\mathrm{n}}$. Science, $\mathbf{2 8 3}, 1148-1150$.

[3] FURUKAWA, H.; CORDOVA, K.E.; O'KEEFFE, M.; YAGHI, O.M. 2013. «The Chemistry and Applications of Metal-Organic Frameworks». Science, 341, 1230444-1-1230444-12.

[4] HE, Y.; ZHOU, W.; QIAN, G.; CHEN, B. 2014. «Methane Storage in Metal-Organic Frameworks». Chem. Soc. Rev., 43, 5657-5678.

[5] SUH, M.P.; PARK, H.J.; PRASAD, T.K.; LIM, D-W. 2012. «Hydrogen Storage in Metal-Organic Frameworks». Chem. Rev., 112, 782-835.

[6] LONG, J.R. 2014. DOE Hydrogen and Fuel Cells Program. FY 2014 Annual Progress Report.

[7] SUMIDA, K.; ROGOW, D.L.; MASON, J.A.; MCDONALD, T.M.; BLOCH, E.D.; HERM, Z.R.; BAE, T.-H.; LONG, J.R. 2012. «Carbon Dioxide Capture in Metal-Organic Frameworks». Chem. Rev., 112, 724-781.

[8] MILLWARD, A.R.; YAGHI, O.M. 2005. «Metal-organic frameworks with exceptionally high capacity for storage of carbon dioxide at room temperature». J. Am. Chem. Soc., 127, 17998-17999.

[9] a) BLOCH, E.D.; QUEEN, W.L.; KRISHNA, R.; ZADROZNY, J.M.; BROWN, C.M.; LONG, J.R. 2012. «Hydrocarbon separations in a metal-organic framework with open iron(II) coordination sites». Science, 335, 16061610. b) LI, J.-R.; SCULLEY, J.; ZHOU, H.-C. 2012. «Metal-Organic Frameworks for Separations». Chem. Rev., 112, 869-932.

[10] a) HERM, Z.R.; WIERS, B.M.; MASON, J.A.; VAN BATEN, J.M.; HUDSON, M.R.; ZAJDEL, P.; BROWN, C.M.; MASCHIOCCHI, N.; KRISHNA, R.; LONG, J.R. 2013. «Separation of Hexane Isomers in a Metal-Organic Framework with Triangular Channels». Science, 340, 960964.

[11] LEE, J.; FARHA, O. K.; ROBERTS, J.; SCHEIDT, K. A.; NGUYEN, S. T.; HUPP, J. T. 2009. «Metal-organic framework materials as catalysts». Chem. Soc. Rev., 38, 1450-1459.

[12] DERIA, P.; MONDLOCH, J. E.; KARAGIARIDI, O.; BURY, W.; HUPP, J. T.; FARHA, O. K. 2014. «Beyond post-synthesis modification: evolution of metal-organic frameworks via building block replacement». Chem. Soc. Rev., 43, 5896-5912.

[13] GASCON, J.; AKTAY, U.; HERNANDEZ-ALONSO, M. D.; VAN KLINK, G. P.; KAPTEIJN, F. 2009. " Amino-based metal-organic frameworks as stable, highly active basic catalysts». J. Catal., 261, 75-87. 
[14] a) HU, Z.; DEIBERT, B. J.; LI, J. 2014. «Luminescent metal-organic frameworks for chemical sensing and explosive detection». Chem. Soc. Rev., 43, 5815-5840. b) HEINE, J.; MÜLLER-BUSCHBAUM, K. 2013. «Engineering metal-based luminescence in coordination polymers and metal-organic frameworks». Chem. Soc. Rev., 42, 9232-9242. c) ALLENDORF, M. D.; BAUER, C. A.; BHAKTA, R. K.; HOUK, R. J. T. 2009. «Luminescent metal-organic frameworks». Chem. Soc. Rev., 38, 1330-1352.

[15] CEPEDA, J.; PÉREZ-YÁÑEZ, S.; BEOBIDE, G.; CASTILLO, O.; GARCÍA, J. A.; LUQUE, A. 2015. «Photoluminescence Tuning and Water Detection of Yttrium Diazinedicarboxylate Materials through Lanthanide Doping». Eur. J. Inorg. Chem., 2650-2663.

[16] XU, H.; RAO, X.; GAO, J.; YU, J.; WANG, Z.; DOU, Z.; CUI, Y.; YANG, Y.; CHEN, B.; QIAN, G. 2012. «A luminescent nanoscale metal-organic framework with controllable morphologies for spore detection». Chem. Commun., 48, 7377-7379.

[17] LAN, A.; LI, K.; WU, H.; OLSON, D. H.; EMGE, T. J.; KI, W.; HONG, M.; LI, J. 2009. «A luminescent microporous metal-organic framework for the fast and reversible detection of high explosives». Angew. Chem., Int. Ed., 48, 2334-2338. 